\title{
Severe Combined Immunodeficiency with Absence of T and B Cells
}

National Cancer Institute

\section{Source}

National Cancer Institute. Severe Combined Immunodeficiency with Absence of $T$ and B

Cells. NCI Thesaurus. Code C61238.

An inherited, severe immunodeficiency disorder characterized by abnormalities in the development and function of $\mathrm{T}$ and $\mathrm{B}$ cell immunity. The peripheral $\mathrm{T}$ and $\mathrm{B}$ lymphocytes are absent or in very low counts. 